\title{
INVESTIGATING MEAT MILLING BUSINESS IN YOGYAKARTA: A MAQÂSHID AL-SYARÎ'AH PERSPECTIVES
}

\author{
Zein Muttaqin' \& Nadia Nuril Ferdaus ${ }^{2}$ \\ ${ }^{1}$ International Islamic University Malaysia (IIUM), Malaysia \\ J. Gombak, Selangor Darul Ehsan, Kuala Lumpur 50728 \\ E-mail: zeinmuttaqin@gmail.com \\ ${ }^{2}$ Universitas Islam Indonesia (UII), Yogyakarta \\ Jalan Kaliurang Km. 14.5, 55584, Yogyakarta, Indonesia \\ E-mail: nadiafirdaus2@gmail.com
}

\begin{abstract}
Investigating Meat Milling Business in Yogyakarta: a Maqâshid al-Syarî́ah Perspectives. This article aims to investigate the meat milling business process in the light of maqâshid al-syarî̃ah perspectives. The topic arises due to some past cases related to the mixed process of meat milling of lawful and unlawful meat in the industry, while the demand on the meat milling business is pretty high according to the BAPPENAS Yogyakarta data. Lacking on supervision has threatened consumer protection and deviates from the sharia injunctions. Maqâshid al-syarî́ah being consider as the basis of sharia compliances that serves to understand the purposes of sharia laws in the daily life in the form of prohibitions and injunctions. Qualitative method and content analysis is conducted to interpret 7 meats milling local shop owner responds regards the manifestation of maqâshid al-syarî́ah in their business. It can be concluded that the implementation of maqâshid al-syarî́ah of meat milling business in Yogyakarta on the level of input, process and output has been implemented accordingly. Although there are several cases of respondent that did not abide by the Islamic laws, but most of the businessman are. Halal logistic and supply chain is needed to become the insurance party of the legal aspect of business and also as the milestone of expanding the local meat milling to compete with the bigger competitor such as supermarket.
\end{abstract}

Keywords: halal industry; halal food; maqâshid al-syarî‘ah.

\begin{abstract}
Abstrak: Investigasi Bisnis Penggilingan Daging di Yogyakarta: Perspektif Maqâshid al-Syarî́ah. Penelitian ini bertujuan untuk menyelidiki proses penggilingan daging dalam perspektif maqâshid al-syarî́ah. Topiknya muncul karena beberapa kasus masa lalu terkait dengan proses campuran penggilingan daging daging yang sah dan tidak sah di industri ini, sementara permintaan pada bisnis penggilingan daging cukup tinggi menurut data BAPPENAS Yogyakarta. Kurangnya pengawasan telah mengancam perlindungan konsumen dan menyimpang dari perintah syariah. Maqâshid al-syarî‘ah dianggap sebagai dasar kepatuhan syariah yang berfungsi untuk memahami tujuan hukum syariah dalam kehidupan sehari-hari dalam bentuk larangan dan perintah. Metode kualitatif dan analisis isi dilakukan untuk menafsirkan 7 buah pemilik toko penggilingan lokal merespon mengenai manifestasi maqâshid al-syarî‘ah dalam usaha mereka. Dapat disimpulkan bahwa penerapan maqâshid al-syarî‘ah usaha penggilingan daging di Yogyakarta pada tingkat input, proses dan output telah dilaksanakan sesuai dengan itu. Meski ada beberapa kasus responden yang tidak mematuhi hukum Islam, namun sebagian besar pebisnis tersebut telah melaksanakannya. Suplai logistik dan logistik halal diperlukan untuk menjadi pihak asuransi dalam aspek hukum bisnis dan juga sebagai tonggak perluasan penggilingan daging lokal untuk bersaing dengan pesaing yang lebih besar seperti supermarket.
\end{abstract}

Kata kunci: industri halal; makanan halal; maqâshid al-syarî́ah.

\section{Introduction}

Business is defined as one of economic activities in pursue of income and profit. In the early of $20^{\text {th }}$, religion is dichotomized to social activities, economics, and politics. Religion is measured by how far and intense in performing prayer only, thus it is not appropriate to be assimilated with the socio-economic-political problems. By the emergence of Islamic economics in the last decade, it has been expanded the horizon of society awareness that the integration of religion (religious values) in the socio-economic 
has pivotal role in shaping the society. Islamic economics abides by the Islamic laws in order to achieve the personal and public wellbeing. ${ }^{1}$ In managing the business, Islamic economics consider normative values and ethics as the framework of performance which assumed leads to better accomplishment.

Since the encouragement year of the creative industry sectors couple years behind, people responded positively in achieving better economic development. Many micro-small-medium- enterprises emerge in response of the policy. The industry scale became more expanded that is expected; even the new era of halal industry became more prominent in strengthening the industry further. ${ }^{2}$ This changing in paradigm of consumer preferences of halal industry is a double edged-sword, which can be enhancing the growth of industry or devastating the industry because of public drawback. Pertaining the term of halal, is one of the fundamental decision-making of an object to consume, which mentioned in the Quran has shifted as part of people lifestyle; either it has been practiced by Muslim or nonMuslim. Hence, halal is a technical measurement of sharia-compliant in particular object which does not contradict to the Islamic Laws.

The needs of the Indonesian people in the culinary business are influenced by various factors of the main source of materials and supporting materials, one of the main source is animal protein, where Indonesian people still entrust their choice to chicken meat and beef meat. The high rate of demand by the society that is not commensurate with the amount of supplies available causes the continued increase in the price of beef, so that it is what encourages business people to commit fraudulent practices to reduce production costs. In 2014, Division of Veterinary Diagnostic, Department of Agriculture Yogyakarta found that there are quite number of cases pork scandal in the meat retail market.

'Bedoui, M. H., "Shari'ah-Based Ethical Performance Measurement Framework", In Chair For Ethics And Financial Norms, 2012, p. 1-12

${ }^{2}$ Rahman, F. K., Tareq, M. A., Yunanda, R. A., \& Mahdzir, A. "Maqashid Al-Shari'ah -based performance measurement for the halal industry", Humanomics, Vol. 33. No.3, 2017, p. $357-370$
In their research, 31 samples of 175 indicated positive has pork substances, and most of the cases from meat beef processed. ${ }^{3}$ Other problems that emerges in the case of mix of pork meat substance in the beef meat processed, was not only due to the intentional mixing or replacement of meat from the beginning to reduce the cost of production, in the long term it might causes the falling demand for other sharia-compliant producers. Hence those practice is surely contaminated the lawful meat to become unlawful one. In their research, Bonne, Vermeir, Bergeaud-Blackler, \& Verbeke argue that Muslim's personal choice for halal meat consumption in contrast with peer's pressure or their motivation to comply with this influence of others. ${ }^{4}$

Maqâshid al-syarî‘ah came into the light as an elaborate reason to understanding and achieve the purpose behind the behest of Islamic laws. The term of maqâshid al-syarî́ah refers to a purpose, objective, principle, intent, goal or end of Islamic rulings. ${ }^{5}$ Imam Al-ghazali explained that maqâshid exists to promote the wellbeing of all mankind, which lies in safeguarding their faith (din), their human self (nafs), their intellect ('aql), their posterity (nasl) and their wealth (maal). ${ }^{6}$ Halal is just one of part of maqâshid al-syarî‘ah implementation that needed to be explored and integrated into many part of industry, especially in the poultry industry.

In the same of problematic issues that conducted by Allam Ahmed, he found that some consumers tend to buy halal meat in the local shop rather in supermarket. The strong reason is the such information is not informed accordingly and also although there is significant difference between buying halal meat in local shops and supermarket. Consumer has undefined propensity to buy halal meats in the local shops rather than

${ }^{3}$ Gusti, "Positif Mengandung Babi, Pemalsuan Daging di DIY Kurang", UGM News Directory, 2014

${ }^{4}$ Bonne, K., Vermeir, I., Bergeaud-Blackler, F., \& Verbeke, W., "Determinants of halal meat consumption in France", British Food Journal, Vol. 109, No. 5, 2007, p. 379

${ }^{5}$ Auda, J. "Maqasid Al-Shariah As Philosophy of Islamic: A System Approach”, Vol. 1, 2007, (Herndon: The International Institute of Islamic Thought)

${ }^{6}$ Dusuki, A. W., \& Abdullah, N. I., "Maqasid al-Shari'ah. Maslahah, and Corporate Social Responsibility", The American Journal of Islamic Social Sciences, Vol. 24, No.1, 2007, p. 25-44. 
supermarket.7 In different perspective, Rahman et.al. found that the concept and measurement of maqâshid al-syarî‘ah has not fully covered many sectors of economic, most of conducted research been circling in the financial sector, although there are some potential sectors that needed to be measured comprehensively. ${ }^{8}$ Thus, the purpose of this paper is to investigate the meat milling process in the light of maqâshid alsyarî'ah perspectives. In order to establish firm's identity and integrated wellbeing of consumer. To reach this goal, this article begins by exploring the discussion on maqâsidhal-syarî́ah and finding some key definitions on the contemporary perspectives. Later then, conducting analysis of collected interviews responds to being further analysed in descriptive forms. Then, it concluded in the discussion of integration of maqâsidhalsyarî' $a h$ in the meat milling industry.

\section{Literature Review}

There were various discussion regarding of maqâshid al-syarî́ah in the economic studies, they are categorized into five main systematized themes in (i) Islamic economics; (ii) Islamic banking; (iii) Islamic finance; (iv) Islamic finance product; (v) economic development. ${ }^{9}$ The term maqâshid alsyarî‘ $a$ h refers to a purpose, objective, principle, intent, goal or end. In the perspective of Islamic laws it can be defined as the purpose of behind Islamic rulings. Furthermore, Auda emphasizes that maqâshid al-syarî̃ah is a significant technique and an intellectual apparatus for Islamic reform by discarded any impression or system borrowed that is not within the context of Islamic erudition and expressions..$^{10}$ In addition, the purpose that discussed in the maqâshid of Islamic law has several various ways of dimensions; they are (i) levels of necessity; (ii) scope of the rulings; (iii) scope of people; (iv) level of universality. ${ }^{11}$ According to Imam al-Ghazali, maqâshid exists to

\footnotetext{
7 Ahmed, A., "Marketing of halal meat in the United Kingdom”, British Food Journal, Vol. 110, No. 7, 2008, p. 655-670

8 Auda, J. "Maqasid Al-Shariah As Philosophy of Islamic: A System..

9 Shinkafi, A. A., \& Ali, N. A., "Contemporary Islamic economic studies on Maqasid Shari'ah : a systematic literature review", Humanomics, Vol. 33, No. 3, 2017, h. 315-334

${ }^{10}$ Shinkafi, A. A., \& Ali, N. A., "Contemporary Islamic..., p. 7

${ }^{11}$ Shinkafi, A. A., \& Ali, N. A., "Contemporary Islamic, p. 7
}

promote the well-being of all mankind, which lies in safe guarding their faith (dîn), their human self (nafs), their intellect ( $a q l)$, their posterity (nasl) and their wealth (mâl). ${ }^{12}$ In 1977, Masud elaborated that maqâshid serves to do two essential things, which is tahsil (i.e. securing the benefit) and ibqa (repelling of harm). ${ }^{13}$ Hence, maqâshid alsyarî'ah indicators developed to pursue the individual and public interest holistically. ${ }^{14}$ The very basis of maqâshid al-syarî́ah is concerning the wellbeing of ummah and became the pillars of design standard of Islamic economic systems that comprehends values and particular standard issues..$^{15}$ This standard is still undergoing some development on certain part of ijtihâd, so that the performance of particular industry which implemented maqâshid al-syarî'ah might be measured accordingly. Bedoui stressed that performance is a consequence and a result of a predetermined objective and a goal. ${ }^{16}$ In case of strategic planning and activities, objectives have crucial means and serve as the performance evaluations that highlighted the relation of decisions and implementation. Previous research of maqâshid al-syarî́ah on takaful intimately has proven measures well and integrated in the framework of maqâshid al-syarî'ah. ${ }^{17}$ The framework that developed in the Islamic finance sectors is actualizing benefit and repelling harm, thus it has endeavour transparent practices. ${ }^{18}$ In pursuance of implementation of maqâshid al-syarî́ah has part of Islamic management indicators, Hadi proposes that (i) preservation of religion indicates by the Islamic firm identity;

${ }^{12}$ Dusuki, A. W., \& Abdullah, N. I., “Maqasid al-Shari’ah. Maslahah, and Corporate Social Responsibility", The American Journal of Islamic Social Sciences, Vol. 24, No. 1, 2007, p. 25-44

${ }^{13}$ Rosly, S. A., "Shariah parameters reconsidered", International Journal of Islamic and Middle Eastern Finance and Management, Vol. 3, No. 2, 2010, p. 132-146

14 Abubakar, Y. S., "Corporate Social Responsibility of Islamic Financial Institutions: A Look from the Maqasid Al-Shariah ( Purpose of Shariah ) Approach", Business and Economics Journal, Vol. 7, No. 4, 2016, p. 1-4

15 Abdullah, S., "Management via Takaful from a Perspective of Maqasid of Shariah", Procedia - Social and Behavioral Sciences, 65(ICIBSoS), 2012, p. 535-541

${ }^{16}$ Bedoui..., h. 4

${ }^{17}$ Abdullah, S., "Management via Takaful..., p. 535-541

${ }^{18}$ Laldin, M. A., \& Furqani, H., "Developing Islamic finance in the framework of maqasid al-Shari'ah", International Journal of Islamic and Middle Eastern Finance and Management, Vol. 6. No. 4, 2013, p. 278-289 
(ii) preservation of life indicates as human resources quality improvement; (iii) preservation of intellect indicates by organizational system; (iv) preservation of lineage indicates by blessings and profits; ( $v$ ) preservation of wealth indicates by capital, sales and financial management. ${ }^{19}$ Maslahah or wellbeing is considered as the main principle of the subsistence of human life, alShatibi classifies maslahah into three categories, dharuriyat (i.e. the essentials are the self-interests upon which people essentially depend, such as faith, life, intellect, posterity, and wealth), hajiyyat (i.e. the complementary interests supplement the essentials and refer to those interests that, if neglected, would lead to hardship but not to the total disruption of life's normal order.), tahsinniyat (i.e. the embellishments refer to those interests that, if realized, would lead to refinement and perfection in the customs and conduct of people at all levels of achievement)..$^{20}$ In summation, the role of maqâshid al-syarî'ah in many industries aims to enhance, enrich, or improve the wellbeing of personal and public interest. ${ }^{21}$

Performance of poultry industry in this case meat Milling business, mostly associated by the halal industry. Thus, the measurement of the industry itself remains limited at the maqâshid al-syarî́ah framework. Shinkafi \& Ali argue that many discussions of maqâshid al-syarî́ah have little or lack total courtesy of the writers. ${ }^{22}$ However, in regard to the halal industry in the poultry industry, leads to belief in making of halal supply chain that being conducted thoroughly for long term case. ${ }^{23}$ Shahijan et. al examined that retailer's intention and actual behaviour positively influenced by religious thought such as subjective norms, normative norms, etc. They propose that religiosity should be taken consideration to be explore further in understanding retailer behaviour. ${ }^{24}$

${ }_{19} \mathrm{Hadi}$, K., "Implementasi Maqoshid Syariah Sebagai Indikator Perusahaan Islami", Jurnal Al-Azhar Indonesia Seri Pranata Sosial, Vol. 1 No. 3, 2012, p. 140-150

${ }^{20}$ Dusuki\& Abdullah..., p. 32-33

${ }^{21}$ Ghulam, Z., "Implementasi Maqashid Syariah Dalam Koperasi Syariah", Iqtishoduna, Vol. 7, No. 1, 2016, p. 90-112

${ }^{22}$ Shinkafi, A. A., \& Ali, N. A., "Contemporary Islamic..., p. 7

${ }^{23}$ Tieman, M., \& Che Ghazali, M., "Principles in halal purchasing", Journal of Islamic Marketing, 4 (3), 2013, p. 281-293

${ }^{24}$ Shahijan, M. K., Rezaei, S., Preece, C. N., \& Ismail, W. K. W., "Examining retailers' behaviour in managing critical points in halal meat handling: a PLS analysis", Journal of Islamic

\section{Method}

This research is conducted using qualitative approach. Qualitative research is a means for exploring and understanding the meaning individuals or groups ascribe to a social or human problem. ${ }^{25}$ This research is considered as the appropriate methodology to reach, investigate, and emphasize the implementation of maqâshid al-syarî́ah in the meat milling business Yogyakarta. Content analysis is used to give some opportunities for understanding several dimensions in analysing the data. Semi structured interview techniques are conducted. Simple random sampling is applied on 31 markets in Yogyakarta which is have meat milling shop and 7 markets is selected that corresponds to the terms, namely Demangan market, Terban Market, Lempuyangan Market, Beringharjo Market, Serangan market, Prawirotaman market, Keranggan Market, while all respondents are the owner of business. Simple random is used from a finite population as a sample which is chosen in such a way that each of possible samples has the same probability. ${ }^{26}$ The data is triangulated by confirming to the owner statement and also to the costumer and staff.

\section{Discussion}

It is admitted for the last couple years the production of meat is increased significantly with the issues of meat scarcity (shown in Figure 1) Despite of the increasing number of meat production, the emergence of halal industry (shown in Figure 2) is also affected also the industry of poultry such as meat milling business, due to high level of awareness of industry, especially for Muslim society. The need of halal practice in the business become more important as a technical solution in preventing of food poisoning as they may introduce pathogens within the entire food. ${ }^{27}$ Meat milling business is

\footnotetext{
Marketing, Vol. 3, 2014, p. 446-472

25 Creswell, J. W., "Research design: Qualitative, quantitative, and mixed methods approaches", Vol. 3rd, 2009, (Singapore: SAGE Publications Asia-Pacific Pte. Ltd.)

${ }_{26}$ Kothari, C. R., "Research Methodology: Methods \& Techniques", 2004, (New Age International (P) Ltd.) p. 60

${ }_{27}$ Smigic, N., Antic, D., Blagojevic, B., Tomasevic, I., \& Djekic, I., "The level of food safety knowledge among meat
} 
categorized as a services business that susceptible with the manipulation of process because of agency problems or not. Thus, this business should be investigated within the input-process-output mechanism, in order to prevent any misleading or malpractice of industry. To interpret further of maqâshid al-syarî́ah in practice, there are several parameters that proposes to be investigated as follows (Figure 3 ).

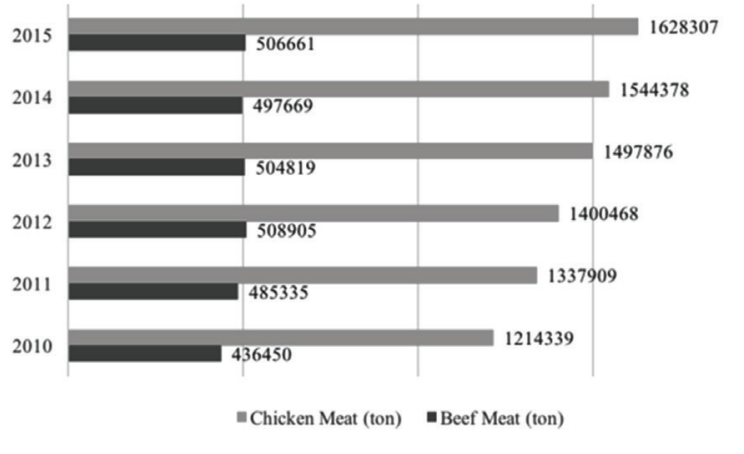

Figure 1

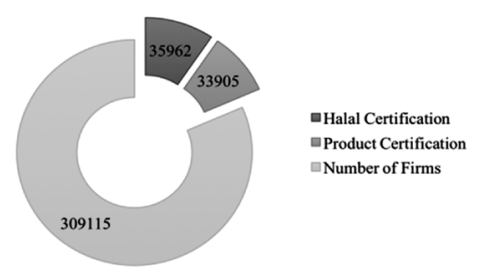

Figure 2

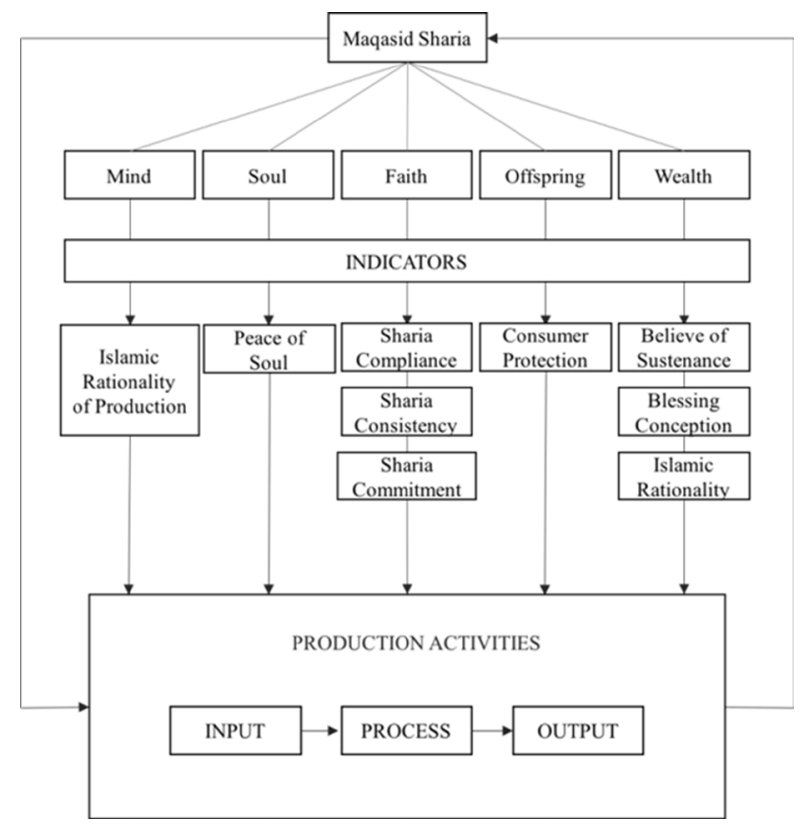

Figure 3

Based on the 7 interview and observation of meat milling process that conducted in 7 market

handlers", British Food Journal, Vol. 118, No. 1, 2008, p. 9-25 in Yogyakarta and took 3 weeks to collect data, it can be discussed further as follows,

\section{The Religion Principles of Meat Milling Business}

The manifestation of religion on Islamic management or Islamic business is leading to the making of firm's identity, this identity manifested by abiding firm into sharia compliance..$^{28}$ Sharia compliance is considered as foremost parameter in explain the preservation of religion. However, the sharia compliance need to be backed up by sharia consistency (i.e. continuation aspect), and sharia commitment (i.e. individual emotional aspect). Based on the investigation, the purpose of preserving religion in meat milling business activities such as input-process-output, found that most of respondent have high respects regards of sharia compliance, sharia consistency, and sharia commitment. Under the respondent statement regarding input of business found that:

"It is an obligation of business provider to assess and distinguish the input (i.e. meat), whether it has halal or haram substances"

"All meat basically consumable, however considering the sharia provisions, we need to leave the questionable meat"

"Sometimes most of consumer does not informed that the meat is unlawful one, this might problematic for our newbie staff"

In light of the input of business, all respondent agrees that the lawful process will leads to the lawful output.

"Obviously, we must never blend such unlawful meat into our services"

"Sometimes we inform our costumer regarding Milling process, even the recipes"

The religion preservation is considered as the main pillars of the meat milling business. Technically, this pillar is associated with halal meat handlers or even the halal branding. The output of implementing maqâshid al-syarî́ah is to fulfil the wellbeing of ummah. 29 Thus it needed to consider food consumption values which consists of (i) product values; (ii) process values;

\footnotetext{
${ }^{28}$ Hadi, K., "Implementasi Maqoshid Syariah..., p. 140-150

${ }_{29}$ Abdullah, S., "Management via Takaful..., p. 535-541
} 
(iii) location values; (iv) emotional values. ${ }^{30}$ In handling such peculiar process in halal or Islamic provisions manner, meat retailer intention and actual behaviour is affected by normative believe, subjective norms, retailer's behavioural belief, and retailer's attitude. ${ }^{31}$

\section{The Life/Soul Principles of Meat Milling Business}

Hadi proposed that the manifestation of life principle in the context of Islamic Firm lies in the improvement of human resources quality. ${ }^{32}$ The finding in this research relatively explained in manner of "feels" (i.e. peace of mind), or subjective and normative norms that being feels by the businessman. ${ }^{33}$ Most of respondent statement agrees that

"It is very relieving while we are not blending such substances into our business, we even worried to our business sustainability even the hereafter punishment if we do such things"

"We never fear of such blended meat scandal, because we always inspect and assess the meat thoroughly"

What have been felt by the businessman is simply proving what has been prescribe by Allah in surah Ar-Ra'ad [13]: 26

"Allah extends provision for whom He wills and restricts [it]. And they rejoice in the worldly life, while the worldly life is not, compared to the Hereafter, except [brief] enjoyment."

\section{The Mind/intellect Principles of Meat Milling Business}

Intellect is considered the very fundamental tools in explaining, understanding, even making a decision on things. According to Hadi, intellect principle is measured based on the use of knowledge in organizing firm. ${ }^{34}$ However, what have been found in this research basically

${ }^{30}$ Dagevos, H., \& van Ophem, J., "Food consumption value: Developing a consumer-centred concept of value in the field of food", British Food Journal, Vol. 115, No. 10, 2013, p. 1473-1486

${ }^{31}$ Shahijan, M. K., Rezaei, S., Preece, C. N., \& Ismail, W. K. W., "Examining retailers' behaviour..., p. 9-25

${ }^{32} \mathrm{Hadi}, \mathrm{K} .$, "Implementasi Maqoshid Syariah..., p. 140-150

${ }^{33}$ Shahijan et.al, "Examining retailers' behaviour..., p. 9-25

${ }^{34} \mathrm{Hadi}, \mathrm{K} .$, "Implementasi Maqoshid Syariah..., p. 140-150 correlated the very basis of Islamic production rationality. In the context of production, Siddiqi (1970) claimed that the Muslim firm should serve the interest of society. Such social good should guide him in his decision beside his own profit. ${ }^{35}$ Here is the statement of respondent regarding the intellect principles,

"We believe in business positively that God's will provides more if it concerns Him, we do not have to go profit oriented blindly and fear of declining in business and opportunity, as long as there is consumer (i.e. tukang bakso) all is well"

"We are a service provider, so we should give excellent services to consumer without risking the business at all"

The element of findings in this research clearly differ what has been proposed by Hadi, ${ }^{36}$ he mentions that intellect should be implement towards the firm's management including purposes, planning, monitoring, leadership, and the concept of tawakkal.

\section{The Lineage/Offspring Principles of Meat Milling Business}

The lineage principles basically refer to the serve of securing benefit and repelling harm. Some scholars suggested that lineage preservation is the key of continuation, whether it is about the individual, public, or public system. In this research, what is conducted is referring to the consumer protection. In the form of Islamic firm, this principle is differed what has been proposed by Hadi, ${ }^{37}$ which stated the continuation of the firm lies in the God blessings and firm profits. This research found that consumer protection is considered in health perspectives. Most of respondent statement concurs that,

"The blending process of lawful and unlawful meat cannot be guarantee have a side effect in health"

"According to doctor unlawful meat has side effect in long term consuming, but most of peoples consuming it seems fine, but for

\footnotetext{
${ }^{35}$ Hallaq, S., "Rationality in Production: The Case of The Muslim Firm", Humanomics, Vol. 11, No. 4, 1995, p. 29-38

${ }^{36} \mathrm{Hadi}, \mathrm{K} .$, "Implementasi Maqoshid Syariah..., p. 140-150

37 Hadi, K., "Implementasi Maqoshid Syariah..., p. 140-150
} 
Muslim is strictly forbidden whether it is not directly effects health"

"Oh, I really believe what God has forbidden in consumption meaning blending meat of lawful and unlawful will be bad for our health"

By blending unlawful and lawful meat into one process might attract some pathogens that might be leading to food poisoning. To prevent such outcome (i.e. food poisoning), retailers needs to enforce the education for its staff, in order to maintain the hygiene and identify the possible pathogens that might be appear..$^{38}$

\section{The Wealth Principles of Meat Milling Business}

Allah had instructed His believers to circulate their wealth, due to temporary ownerships as God's bounty and trust. Wealth circulation includes all the process related to wealth creation, consumption and distribution. ${ }^{39}$ According to Hadi Islamic management of firms, that integrated with maqâshid al-syarî́ah is manifested on capital that earned and managed; sales; and financial management which not engaging with riba practice..$^{40}$ Most of respondent agrees that wealth needs to be circulated,

"Most of money is set aside for the accumulation of zakat by the end of the zakat's tempo"

"We paid zakat each year, but sometimes went to orphanage every Monday and Thursday if we made mistakes as penance"

"We do not really understand how blessing works, but we can feel it in every aspect of our business, for instance many costumer, quite amount of profits"

The implication of wealth principle in the business reflected by the annual application of zakah. Zakah as one pillar of Islamic faith also known a religious levy or almsgiving. On the maqasid perspective, most of meat milling businessman carry out zakah as calling for the increasing of wealth materially or spiritually.

\footnotetext{
${ }_{38}$ Smigic et.al "The level of food safety knowledge among..., p. 9-25.

39 Laldin, M. A., \& Furqani, H., "Developing Islamic finance..., p. 278-289.

${ }^{40}$ Hadi, K., "Implementasi Maqoshid Syariah..., p. 140-150.
}

According to Saad, Wahab, \& Samsudin, there are two main factors of zakah-compliance behaviour, internal factors and external factors. ${ }^{41}$ Internal factors consist of knowledge and selfefficacy. External factors consist of service quality and interaction. Knowledge and self-efficacy become the main reasons why the businessman compliance to pay zakah annually.

\section{Integrated Maqâshid al-Syarî'ah in Meat Milling Business as Halal Industy}

Based on the investigation, it is known that maqâshid al-syarî́ah has pivotal role in order to give high remarks of integrated business in light of sharia values. Considering maqâshid alsyarî'ah is integrated into the business, it leads to more prominent business that has high level of technical implementation of halal industry and business ethics. Although, Rahman, et.al. stated that the development of maqâshid al-syarî́ah performance measurement has not been carried out comprehensively in non-financial industry. ${ }^{42}$ While the business in conducted ethically in achieving high performance maqâshid al-syarî‘ah, Islamic ethics is affected business in several ways, such as (i) increase effectiveness and efficiency; (ii) lead to integrity; (iii) cause a Muslim business person to abstain from cheating and deceit; (iv) prevent corruption and abuse of power; ( $v$ ) lead to better care of employees and their rights; (vi) lead to consistent consultation and cooperation; (vii) create initiative; (viii)lead to better quality. ${ }^{43}$ One think that need to be assure is meat milling business is one part of halal industry. In respect to poultry industry, the milling meat has particular business competitor that differs from the local market and supermarket. A case in UK, most of Muslim do not trust big supermarket when buying halal meat, they will only trust the local shops. This happens due to lacking information about the big supermarket that provided halal meat,

${ }^{41}$ Saad, R. A. J., Wahab, M. S. A., \& Samsudin, M. A. M., "Factors Influencing Business Zakah Compliance Behavior among Moslem Businessmen in Malaysia: A Research Model", In Procedia - Social and Behavioral Sciences Vol. 219, 2016, p. 654-659).

42 Rahman, at.al. "Maqashid Al-Shari'ah..., p. 357-370.

${ }^{43}$ Abuznaid, S. A., "Business ethics in Islam: the glaring gap in practice", International Journal of Islamic and Middle Eastern Finance and Management, Vol. 2, No. 4, 2009, p. 278-288. 
they still rewarding the local shops because of long good relationship and loyalty matter. ${ }^{44}$ This highlight the potential market of consumer market in Yogyakarta, which dominantly middle-income earner. Supermarket has its own advantages by assuming highly level of hygiene compare to the local shops. Thus, the local shops (i.e. milling meat retailer) needs to improve their quality assurance and services of consumer. The quality meat is a subjective preferences among consumer, but it must has its own standard that adopt to the local grading and standard. ${ }^{45}$ In order to get the desirable product, Woodward proposes that quality of meat is not the only thing that matters, local retailers needs to consider, (i) product ingredient; (ii) percentage of fat present; (iii) the use of additives; (iv) convenience factors; (v) preparation portions. ${ }^{46}$

Meat milling business as service provider business, partially involves the production process. The process is highly susceptible to the production abuse. In Islamic economics, behaviour of Muslim firm is expected to differ from non-Muslim firm. ${ }^{47}$ Muslim production has three implication they are, (i) products which deprive the human being of his moral values as established in the Quran are prohibited; (ii) the social aspect of production is emphasized and intimately related to the production process; (iii) the economic problem is not one of scarcity in relation to needs but it caused by human laziness and neglect in the extraction of the full benefits of Allah's gifts. ${ }^{48}$ Furthermore, Siddiqi (1972) mentions several goals of economic enterprise in Islam, which are (i) the fulfilment of one's own needs in moderation; (ii) meeting the needs of one's family; (iii) provision for future

\footnotetext{
${ }^{44}$ Ahmed, A., "Marketing of halal meat..., p. 655-670

${ }^{45}$ Subratty, a. H., \& Gurib, F. B. H., Consumers' concern about meat and meat products quality offered for sale in Mauritius", Nutrition \& Food Science, Vol. 33, No. 2, 2003, p. $80-83$

${ }^{46}$ Woodward, J., "Consumer Attitudes Towards Meat And Meat Products", British Food Journal, Vol. 90, No. 3, 1988, p. 101-104

47 Hallaq "Beyond Rationalism: The Role Of Values..., p. 20-39

${ }^{48}$ Kahf, M., "The Theory of Production. In The Islamic Economy: Analytical Study of The Functioning of The Islamic Economic System", (Plainfield, Ind: The Muslim Student's Association of The United State and Canada), 1978, p. 29-38
}

contingencies; (iv) provision for posterity; (v) social service and contribution to the cause of Allah. ${ }^{49}$ In production, rationality implies that individuals must attempt to achieve both their material needs in accordance to the Islamic laws and their spiritual needs, which are obtained through the obedience of God. ${ }^{50}$ This also implies that maqâshid al-syarî'ah manifested rationality as part of measurement framework. The needs of maqâshid al-syarî́ah in the non-financial business such as meat milling business is to define further the consequence of maslahah or wellbeing cumulatively.

The integration of maqâshid al-syarî́ah in this business will become the frontier of developing halal logistic and supply chain. Halal logistic and supply chain proven to be needed by the retailers to assure the quality input of product. In the research that conducted by Shahijan et.al found that effective halal logistics and supply chain management will lead to high performance for retail in halal market. ${ }^{51}$

Managing halal meat becomes an issue for retailers and firms due to consumers concern of their realign thought and quality and safety of food. This also align to the previous findings of preservation of lineage, which justified by the consumer protection. It is clear that halal has clear implications for the purchasing function, where halal has conventionally been addressed by the industry as part of a product specification. A halal procurement maturity model could provide guidance in establishing a solid procurement function based on Islamic values. The proposed halal procurement maturity model recognises three stages: (i) viewing halal compliance as opportunity; (ii) making supply chains halal; and (iii) making value chains halal. ${ }^{52}$ As logistics bridges the gap between the point of production and the point of consumer purchase, the logistics of halal food is fundamental to ensure the integrity

49 Kahf. "The Theory of Production. In The Islamic Economy: Analytical ..., p. 29-38

$5^{0}$ Hallaq, S. "Beyond Rationalism: The Role Of Values And Emotions In An Islamic Economy”, Humanomics, Vol. 13, No. 1, 1997, p. 20-39

${ }^{51}$ Shahijan et.al, “Examining retailers' behaviour..., p. 9-25

52 Tieman\&CheGhazali "Principles in halal purchasing", Journal of Islamic Marketing, 4(3), 2013, p. 281-293 
of halal food at the point of consumption.53 This would be also highlight the food safety issues, where the sense of responsibility for food safety, barriers hindering appropriate food safety practices, and the influences of others, are highlighted through future professional food handlers' perspectives at the end of their formal education. ${ }^{54}$ Formal education might be considered in terms of handling the milling industry. According to the preservation of intellect which proposes by Hadi, by improving some educational addition into the staff is highly improve the level of human resources quality. 55 Preserving intellect can be measured first-hand by interpreting the subjective and normative norms and also the comprehension of business deeply which leads to the staff responsibility. The lower sense of responsibility and optimism bias in the case of food preparation in the domestic environment could be, as demonstrated by Frewer et al. (1994), related to the perceived low personal risk, leading to the participants' misapprehension that they are less susceptible to health consequences than others. ${ }^{56}$ This will contradict to the maqâshid al-syarî'ah that needs to be implemented in the meat milling business.

\section{Conclusion}

The recent contemporary issues on maqâshid al-syarî'ah is emerged and implemented in many sector of economics, although it has to be admitted that measurement and further deep discussion in regards of maqâshid al-syarî́ah still limited in other areas besides financial sector. However, based on the investigation is proven that meat milling business has implemented maqâshid al-syarî́ah accordingly. There are also intriguing finding that it relates to the integrated production which consists of input-process-output, most of respondents consistently abide in the Islamic injunctions, although in some cases there

\footnotetext{
53 Tieman, M., van der Vorst, J. G. A. J., \& Che Ghazali, M., "Principles in halal supply chain management", Journal of Islamic Marketing, Vol. 3, No. 3, 2012, p. 217-243

${ }^{54}$ Ovca, A., Jevšnik, M., \& Raspor, P., "Future professional food handlers' perspectives towards food safety", British Food Journal, Vol. 119, No. 2, 2017, p. 441-424.

55 Hadi, K., "Implementasi Maqoshid Syariah..., p. 140-150

56 Ovca et.al .'Future professional food handlers' perspectives..., p. 441-424.
}

might be a process distortion because of agency problems. Furthermore, halal logistic and supply chain is needed to become the insurance party of the legal aspect of business and also as the milestone of expanding the local meat milling to compete with the bigger competitor such as supermarket. One thing that had been highlighted is that the investigation using interview is limited only on exploratory studies, thus it advise for future research to investigate the specified parameter of maqâshid al-syarî́ah in quantitative model, which covered on samples and research constancy.

\section{Reference}

Abdullah, S., "Management via Takaful from a Perspective of Maqasid of Shariah", Procedia - Social and Behavioral Sciences, 65 (ICIBSoS), 2012.

Abubakar, Y. S., "Corporate Social Responsibility of Islamic Financial Institutions : A Look from the Maqasid Al-Shariah (Purpose of Shariah) Approach", Business and Economics Journal, Vol. 7, No. 4, 2016.

Abuznaid, S. A., "Business ethics in Islam: the glaring gap in practice", International Journal of Islamic and Middle Eastern Finance and Management, Vol. 2, No. 4, 2009.

Ahmed, A., "Marketing of halal meat in the United Kingdom", British Food Journal, Vol. 110, No. 7, 2008.

Auda, J. "Maqasid Al-Shariah As Philosophy of Islamic: A System Approach", Vol. 1, 2007, (Herndon: The International Institute of Islamic Thought)

Bedoui, M. H., "Shari'ah-Based Ethical Performance Measurement Framework", In Chair For Ethics And Financial Norms, 2012

Bonne, K., Vermeir, I., Bergeaud-Blackler, F., \& Verbeke, W., "Determinants of halal meat consumption in France", British Food Journal, Vol. 109, No. 5, 2007

Creswell, J. W., "Research design: Qualitative, quantitative, and mixed methods approaches", Singapore: SAGE Publications Asia-Pacific Pte. Ltd, Vol. 3rd, 2009.

Dagevos, H., \& van Ophem, J., "Food consumption value: Developing a consumer-centred concept of value in the field of food", British Food Journal, Vol. 115, No. 10, 2013. 
Dusuki, A. W., \& Abdullah, N. I., "Maqasid alShari'ah. Maslahah, and Corporate Social Responsibility", The American Journal of Islamic Social Sciences, Vol. 24, No.1, 2007.

Ghulam, Z., "Implementasi Maqashid Syariah Dalam Koperasi Syariah", Iqtishoduna, Vol. 7, No. 1, 2016.

Gusti, "Positif Mengandung Babi, Pemalsuan Daging di DIY Kurang”, UGM News Directory, 2014

Hadi, K., "Implementasi Maqoshid Syariah Sebagai Indikator Perusahaan Islami", Jurnal Al-Azhar Indonesia Seri Pranata Sosial, Vol. 1 No. 3, 2012.

Hallaq, S. "Beyond Rationalism: The Role Of Values And Emotions In An Islamic Economy", Humanomics, Vol. 13, No. 1, 1997.

, "Rationality in Production: The Case of The Muslim Firm”, Humanomics, Vol. 11, No. 4, 1995.

Kahf, M., "The Theory of Production. In The Islamic Economy: Analytical Study of The Functioning of The Islamic Economic System", Plainfield, Ind: The Muslim Student's Association of The United State and Canada, 1978.

Kothari, C. R., "Research Methodology: Methods \& Techniques", New Age International $(P)$ Ltd, 2004.

Laldin, M. A., \& Furqani, H., “Developing Islamic finance in the framework of maqasid alShari'ah", International Journal of Islamic and Middle Eastern Finance and Management, Vol. 6. No. 4, 2013.

Ovca, A., Jevšnik, M., \& Raspor, P., "Future professional food handlers' perspectives towards food safety", British Food Journal, Vol. 119, No. 2, 2017.

Rahman, F. K., Tareq, M. A., Yunanda, R. A., \& Mahdzir, A. "Maqashid Al-Shari'ah -based performance measurement for the halal industry", Humanomics, Vol. 33. No.3, 2017
Rosly, S. A., "Shariah parameters reconsidered", International Journal of Islamic and Middle Eastern Finance and Management, Vol. 3, No. 2, 2010.

Saad, R. A. J., Wahab, M. S. A., \& Samsudin, M. A. M., "Factors Influencing Business Zakah Compliance Behavior among Moslem Businessmen in Malaysia: A Research Model", In Procedia - Social and Behavioral Sciences Vol. 219, 2016.

Shahijan, M. K., Rezaei, S., Preece, C. N., \& Ismail, W. K. W., “Examining retailers' behaviour in managing critical points in halâl meat handling: a PLS analysis", Journal of Islamic Marketing, Vol. 3, 2014.

Shinkafi, A. A., \& Ali, N. A., "Contemporary Islamic economic studies on Maqasid Shari'ah : a systematic literature review", Humanomics, Vol. 33, No. 3, 2017.

Smigic, N., Antic, D., Blagojevic, B., Tomasevic, I., \& Djekic, I., "The level of food safety knowledge among meat handlers", British Food Journal, Vol. 118, No. 1, 2008

Subratty, a. H., \& Gurib, F. B. H., Consumers' concern about meat and meat products quality offered for sale in Mauritius", Nutrition \& Food Science, Vol. 33, No. 2, 2003.

Tieman, M., \& Che Ghazali, M., "Principles in halâl purchasing", Journal of Islamic Marketing, 4(3), 2013.

Tieman, M., van der Vorst, J. G. A. J., \& Che Ghazali, M., "Principles in halâl supply chain management", Journal of Islamic Marketing, Vol. 3, No. 3, 2012.

Woodward, J., "Consumer Attitudes Towards Meat And Meat Products", British Food Journal, Vol. 90, No. 3, 1988. 